\title{
Pola Perubahan Transmisi Infeksi HIV di Jawa Barat Periode Tahun 2002-2012
}

\author{
Ridiani Prawitri, Tony Djajakusumah, Dicky Santosa \\ Universitas Islam Bandung
}

\begin{abstract}
Abstrak
Human immunodeficiency virus (HIV) adalah retrovirus yang termasuk golongan virus RNA yang menginfeksi sel sistem kekebalan tubuh manusia. Infeksi HIV masih menjadi masalah kesehatan masyarakat di dunia dan dilaporkan terjadi pola perubahan transmisi infeksi HIV dari tahun ke tahun di negara tertentu. Tujuan penelitian ini adalah mendeskripsikan dan menganalisis pola perubahan transmisi infeksi HIV di Jawa Barat pada periode tahun 2002 sampai 2012. Penelitian ini dilakukan secara observasional deskriptif dengan pendekatan retrospektif melalui data tersier berupa laporan pengidap infeksi HIV dan kasus AIDS yang diterima oleh Dinas Kesehatan Provinsi Jawa Barat dari Dinas Kesehatan Kabupaten/Kota dan Rumah Sakit di Jawa Barat pada tahun 2002 sampai dengan 2012. Penelitian dilakukan selama Desember 2013-Juli 2014. Hasil penelitian menunjukkan pola perubahan transmisi yang terjadi di Jawa Barat pada tahun 2002 sampai dengan tahun 2012. Jumlah kasus infeksi HIV melalui transmisi homoseksual yaitu 286 kasus, transmisi heteroseksual 1.519 kasus, jarum suntik 1.408 kasus, transmisi ibu ke anak 140 kasus, dan transfusi darah sebanyak 7 kasus. Terjadi perubahan pada tahun 2011 sampai dengan tahun 2012 yaitu peningkatan transmisi heteroseksual menggantikan posisi transmisi pengguna jarum suntik. Keadaan sempat menurunnya transmisi kasus infeksi HIV melalui jarum suntik di Jawa Barat karena penanggulangan pemerintah yang melakukan terapi rumatan metadon. Peningkatan transmisi heteroseksual yang terjadi dapat dipengaruhi oleh faktor norma budaya, maraknya industri prostitusi, status ekonomi, dan pergaulan remaja muda hedonis yang terjadi di lingkungan masyarakat.
\end{abstract}

Kata kunci: Infeksi HIV, pola perubahan, transmisi

\section{Changes of Human Immunodeficiency Virus in West Java Indonesia in Year 2002-2012}

\begin{abstract}
Human immunodeficiency virus is a class of retrovirus which has RNA carrying its molecular genetic that infects the human immune system cells. HIV infection has become global issue and has reported there has been pattern changes of HIV transmission in a certain country. The aim of the study was to describe and analyze the pattern changes of HIV transmission in West Java, Indonesia in year 2002 to 2012. The study was an observational descriptive study with retrospective approach using tertiary form of HIV infections and AIDS cases report which was accepted by Provincial Health Office of West Java from Health Office of District Municipality and Hospital in West Java in 2002 to 2012. The study was held in December 2013 to July 2014. The results showed there were pattern changes of HIV transmission in West Java in 2002 to 2012. There were 286 cases of HIV infection due to homosexual transmission, 1,519 cases due to heterosexuals, 1,408 cases due to injection drug users, 140 cases due to mother to child transmission, and 7 cases due to blood transfusion. There were pattern changes in 2011 until 2012 that injection drug users transmission replaced by heterosexual transmission which has had the highest number with HIV infection. Decreased of HIV infection rates caused by injection drug users could be caused by government policies to prevent HIV by using methadone therapies. The increased of heterosexual transmission could be caused by culture, prostitution industry, economic status, and hedonic teen promiscuity which has happened in community.
\end{abstract}

Key words: HIV infection, pattern changes, transmission

Korespondensi: tonydjajakusumah@yahoo.com 


\section{Pendahuluan}

Human immunodeficiency virus atau acquired immune deficiency syndrome masih menjadi masalah kesehatan masyarakat di dunia. Telah dilaporkan bahwa sejak kasus AIDS pertama kali diidentifikasi pada tahun 1981, sekitar 60 juta orang di dunia terinfeksi HIV dan 25 juta orang di antaranya telah meninggal karena AIDS. Saat ini terdapat 35 juta orang hidup dengan HIV. Diperkirakan terdapat 7.400 kasus infeksi HIV terjadi setiap hari. Pada tahun 2007 terdapat 2,7 juta kasus baru infeksi HIV dan 2 juta orang di antaranya telah meninggal karena AIDS serta penyakit penyerta lainnya.

Di Amerika Serikat telah terdapat lebih dari 600.00o kasus AIDS dilaporkan sejak tahun 1981 dan dapat diperkirakan sebanyak 900.000 penduduk telah terinfeksi HIV. Dilaporkan pada periode 1985 sampai 2006, peningkatan mencapai tiga kali lipat pada wanita dibanding dengan pria, oleh karena itu maka AIDS menjadi penyebab kematian keempat pada wanita usia 25 sampai 44 tahun. ${ }^{2}$

Jumlah penderita HIV untuk semua kategori transmisi di Amerika Serikat paling tinggi di Kota New York. Transmisi melalui homoseksual menempati urutan tertinggi lalu diikuti oleh heteroseksual dan penggunaan jarum suntik. ${ }^{3}$

Pada tahun 1999 terdapat sebanyak 20\% dari 5,6 juta infeksi baru dunia terjadi di kawasan Asia Tenggara. ${ }^{2}$ Pada tahun 2001 sampai dengan tahun 2011 menumjukkan peningkatan insidensi mencapai lebih dari $25 \%$ pada usia 15 sampai 49 tahun. ${ }^{4}$ Di Thailand khususnya di Provinsi Chiang Mai, menurut hasil penelitian variabel demografik menunjukkan bahwa $61,2 \%$ pasien AIDS adalah pria, sedangkan 38,8\%-nya wanita. Berdasarkan usia, 43,6\% pasien AIDS berusia 30-39 tahun, keadaan ini merupakan insidensi paling tinggi berdasarkan usia, sedangkan yang paling rendah pada usia $10-19$ tahun. $^{5}$

Pola perubahan transmisi HIV khususnya di Thailand memiliki lima tahapan epidemik. Tahap pertama pada tahun 1984, populasi yang terinfeksi mencapai 10.000 orang atau $10 \%$ dari seluruh jumlah populasi karena transmisi homoseksual. Pada 4 (empat) tahun berikutnya atau tahun 1988 kelompok pengguna jarum suntik sudah mencapai 40.000 orang terinfeksi HIV atau $40 \%$ dari seluruh jumlah populasi, berlanjut pada tahun 1989 transmisi infeksi HIV mengalami perubahan menjadi heteroseksual yaitu pada pekerja seks wanita sebagai kelompok risiko tertinggi yaitu 56.000 orang atau $28 \%$ dari semua populasi. Pada tahun 1990 kelompok risiko nara kontak dan para pekerja seks wanita meningkat yaitu mencapai 320.000 orang atau 8\% dari semua populasi. Lalu pada tahun 1991 berubah menjangkit wanita lajang, ibu rumah tangga, dan bayi sebanyak 324.000 atau $1,8 \%$ dari semua populasi. ${ }^{6}$

Epidemi AIDS di Indonesia merupakan salah satu epidemi yang mempunyai perkembangan tercepat di Asia. Diperkirakan tanpa peningkatan upaya pengembangan dan pengendalian untuk pencegahan, pengobatan, kepedulian, dan juga dukungan yang dilakukan, mungkin Indonesia akan mempunyai dua kali lipat populasi infeksi HIV dan AIDS. Keadaan ini diperkirakan dapat meningkatkan infeksi HIV dan AIDS sejak tahun 2008, dari sekitar 227.700 orang akan menjadi sebanyak 501.400 orang pada tahun $2014 .^{1}$ Data kumulatif infeksi HIV yang dilaporkan sampai periode bulan September tahun 2013 berdasarkan atas provinsi, ternyata DKI Jakarta menempati urutan pertama sebanyak 27.224 orang, Jawa Timur 15.273 orang, Papua 12.840 orang, danyang keempatyaitu Jawa Barat dengan 9.340 orang. ${ }^{7}$ Pola transmisi di Indonesia sejak kasus AIDS pertama diidentifikasi mengalami peningkatan terutama pengguna jarum suntik. Dimulai pada tahun 2000, prevalensi infeksi HIV mencapai lebih dari $5 \%$ pada beberapa populasi seperti pengguna jarum suntik, pekerja seksual komersial, waria, dan homoseksual. Hal tersebut menyebabkan Indonesia menjadi negara epidemi terpusat dengan HIV/AIDS. ${ }^{1}$

Jawa Barat adalah provinsi dengan penduduk terpadat di Indonesia dengan angka kejadian HIV menempati urutan ke- $4 .{ }^{8}$ Tujuan penelitian untuk mengetahui berapa jumlah kasus infeksi HIV dan pola perubahan transmisi infeksi HIV khususnya di Jawa Barat pada tahun 2002 sampai dengan 2012.

\section{Metode}

Penelitian ini dilakukan secara observasional deskriptif dengan pendekatan secara retrospektif untuk melihat pola perubahan transmisi infeksi HIV. Populasi target adalah semua penderita HIV di Jawa Barat periode tahun 2002 sampai dengan tahun 2012.

Bahan penelitian ini diambil dari data tersier berupa laporan pengidap infeksi HIV dan kasus AIDS yang diterima oleh Dinas Kesehatan 
Provinsi Jawa Barat dari Dinas Kesehatan Kabupaten/Kota dan Rumah Sakit di Jawa Barat pada tahun 2002 sampai dengan 2012.

Penelitian dilaksanakan selama Desember 2013-Juli 2014.

\section{Hasil}

Hasil penelitian pola perubahan transmisi infeksi HIV di Jawa Barat periode tahun 2002 sampai dengan 2012 akan lebih terperinci dijelaskan dalam bentuk gambar serta uraian di bawah ini.

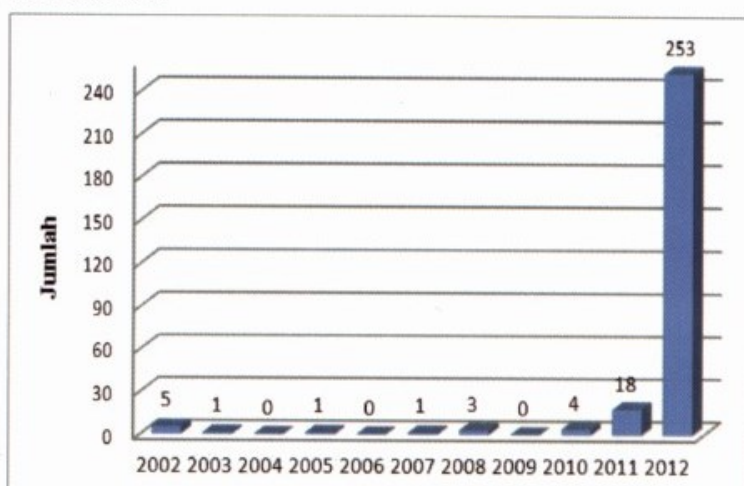

Gambar 1 Grafik Presentase Kasus Infeksi HIV berdasarkan Transmisi Homoseksual di Jawa Barat Tahun 2002-2012

Gambar 2 memperlihatkan jumlah kasus infeksi HIV berdasarkan transmisi heteroseksual di Jawa Barat pada tahun 2002 sampai dengan tahun 2012 sebanyak 1.519 kasus atau 15,16\% dari 10.020 total kasus infeksi HIV. Pada tahun 2004 terjadi peningkatan yang sebelumnya 23 kasus pada tahun 2003 menjadi 69 kasus pada tahun 2004. Peningkatan terjadi pada tahun

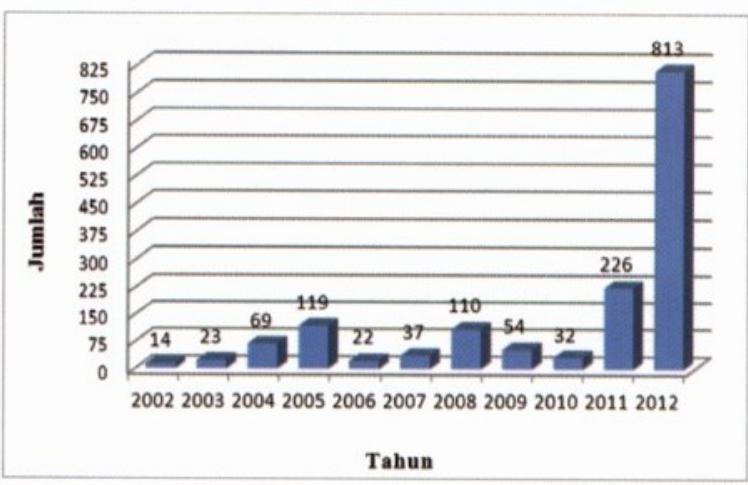

Gambar 2 Grafik Jumlah Kasus Infeksi HIV berdasarkan Transmisi Heteroseksual di Jawa Barat Tahun 2002-2012
2012, dari 226 kasus pada tahun 2011 menjadi 813 kasus pada tahun 2012.

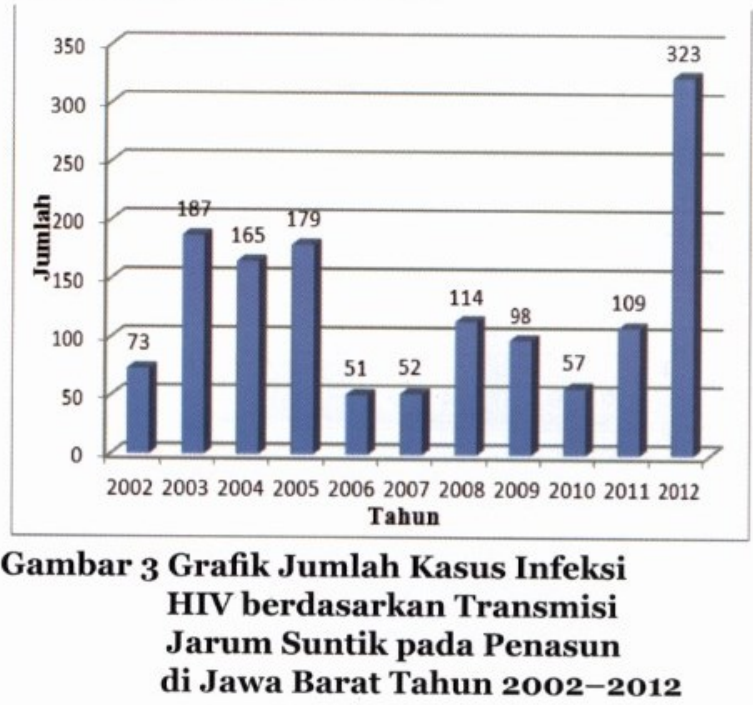

Pada Gambar 3 terlihat jumlah kasus infeksi HIV berdasarkan transmisi jarum suntik pada penasun di Jawa Barat pada tahun 2002-2012 sebanyak 1.408 kasus $(14,05 \%)$ dari 10.020 total kasus infeksi HIV. Pada tahun 2002 jumlah kasus infeksi HIV sudah cukup tinggi yaitu 73 kasus lalu meningkat pada tahun 2003 menjadi 187 kasus. Setelah tahun 2003 dan seterusnya mengalami peningkatan dan penurunan sampai pada tahun 2012, kemudian kembali meningkat pada tahun 2012 menjadi 323 kasus.

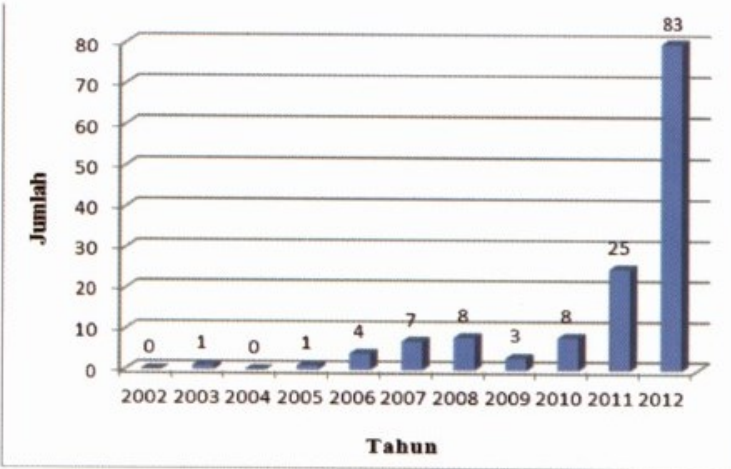

Gambar 4 Grafik Jumlah Kasus Infeksi HIV berdasarkan Transmisi Ibu ke Anak di Jawa Barat Tahun 2002-2012

Pada Gambar 4, jumlah kasus infeksi HIV berdasarkan transmisi dari ibu ke anak di Jawa Barat pada tahun 2002-2012 sebanyak 140 kasus atau 1,4\% dari 10.020 total kasus infeksi HIV. Peningkatan terjadi pada tahun 2012 yaitu sebelumnya 25 kasus pada tahun 2011 menjadi 
83 kasus pada tahun 2012.

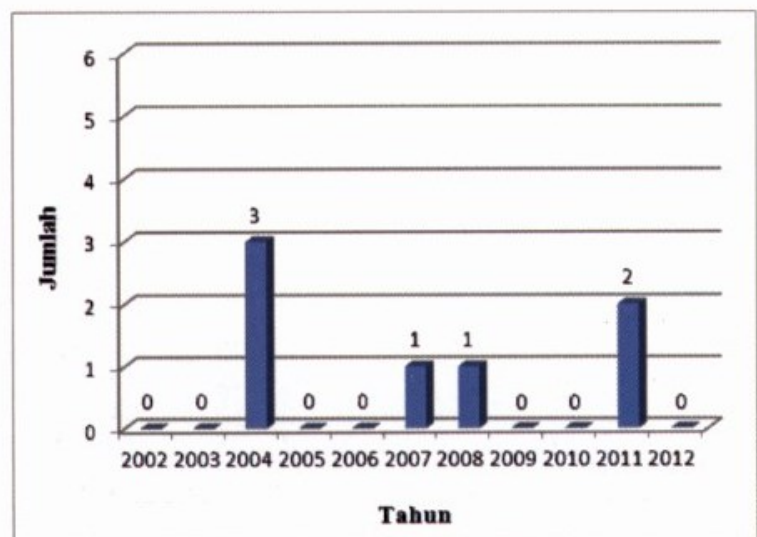

Gambar 5 Grafik Persentase Kasus Infeksi HIV berdasarkan Transfusi Darah di Jawa Barat Tahun 2002-2012

Berdasarkan Gambar 5, jumlah kasus infeksi HIV melalui transfusi darah di Jawa Barat pada tahun 2002-2012 sebanyak 7 kasus atau 0,07\% dari 10.020 jumlah kasus infeksi HIV. Jumlah kasus infeksi HIV berdasarkan transmisi melalui transfusi darah memiliki jumlah yang tinggi hanya pada tahun 2004, sedangkan pada tahun lainnya hanya sedikit peningkatan, bahkan pada tahun 2012 sudah tidak terjadi kasus infeksi HIV melalui transfusi darah.

Pada Gambar 6 terlihat bahwa jumlah kasus infeksi HIV di Jawa Barat tahun 20022012 berdasarkan semua transmisi sebanyak 10.020 kasus. Pola perubahan transmisi infeksi HIV di Jawa Barat pada tahun 2002-2012 untuk transmisi homoseksual relatif stabil tidak ada perubahan kecuali pada tahun 2012 terjadi peningkatan. Angka kejadian transmisi

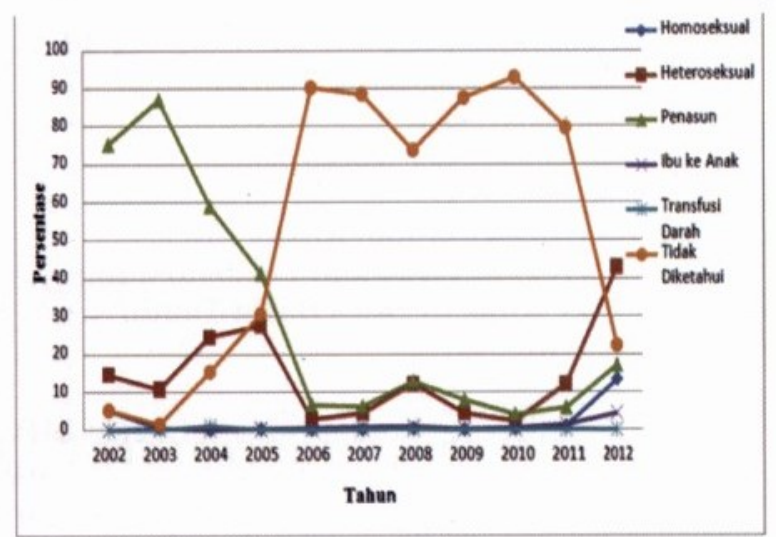

Gambar 6 Grafik Persentase Kasus Infeksi HIV berdasarkan Transmisi di Jawa Barat Tahun 2002-2012 heteroseksual tersebut cenderung lebih rendah pada tahun 2002, lalu pada tahun 2004 dan 2005 mengalami peningkatan. Begitu pula pada tahun 2012 mengalami peningkatan dengan angka tertinggi sepanjang tahun 2002-2012.

Pada transmisi jarum suntik, dari tahun 2002 sudah menempati angka tertinggi dibandingkan dengan seluruh transmisi infeksi HIV. Angka kejadian infeksi mengalami peningkatan sampai mencapai puncaknya pada tahun 2003. Menuju akhir tahun 2011 naik turun lalu sampai tahun 2012 mengalami sedikit peningkatan lagi. Untuk transmisi dari ibu ke anak dan transfusi darah tidak terdapat perubahan dari tahun 20022011. Angka kejadiannya relatif sedikit kecuali pada tahun 2012 mengalami peningkatan untuk ibu ke anak, sebaliknya pada tahun 2012 kasus infeksi HIV dengan transmisi transfusi darah sama sekali tidak terjadi. Selanjutnya, kasus infeksi HIV yang transmisinya tidak diketahui cenderung tinggi pada tahun 2006-2011, tetapi semakin menurun pada tahun 2012.

\section{Pembahasan}

Penelitian yang dilakukan berdasarkan data kasus infeksi HIV diJawa Barat dari tahun 20022012 ditemukan 10.020 kasus. Pola perubahan yang terjadi pada transmisi homoseksual yaitu terdapat penurunan jumlah kasus infeksi HIV pada tahun 2002-2003 yaitu 5,15\% menjadi 0,46\%. Dari tahun 2003-2011, jumlah kasus infeksi HIV cenderung stabil pada angka $<1 \%$. Perubahan terlihat pada tahun 2012, jumlah kasus infeksi HIV meningkat dari o,96\% pada tahun 2011 menjadi 13,35\% pada tahun 2012.

Keadaan yang berbeda terjadi di India pada penelitian Prasad 9 yang berjudul "An insight into HIV/AIDS epidemic in India and India's response" pada tahun 2012, terjadi peningkatan dan penurunan dari tahun 2003 sampai dengan tahun 2008. Sesudah itu jumlahnya mengalami penurunan pada tahun 2008 dari $7 \%$ menjadi 5\% pada tahun 2010. Jumlah kasus infeksi HIV melalui transmisi homoseksual di India mengalami puncak tertinggi pada tahun 2005 yaitu $8,8 \%$.

Kesadaran akan HIV yang rendah di antara homoseksual dapat mengakibatkan beberapa faktor peningkatan transmisi infeksi HIV, yaitu di antaranya meremehkan risiko yang akan terjadi pada seseorang setelah terinfeksi HIV sehingga akan dengan mudah mentransmisikan infeksi tersebut kepada orang lain. Faktor stigma 
dan diskriminasi masyarakat terhadap pelaku homoseksual juga dapat mengakibatkan pelaku homoseksual lebih sulit untuk mengakui kepada dunia luar tentang perilaku seksualnya sehingga dapat memengaruhi kesehatan dan membatasi dukungan sosial. Oleh karena itu, dapat menjadi alasan mengapa kasus infeksi HIV di Jawa Barat yang melalui transmisi homoseksual semakin meningkat, khususnya pada tahun 2012. ${ }^{10}$

Pola perubahan kasus infeksi HIV melalui transmisi heteroseksual tersebut pada tahun 2002-2012 di Jawa Barat terjadi peningkatan, sebelumnya 10,7\% pada tahun 2003 menjadi $24,64 \%$ pada tahun 2004. Peningkatan terjadi pada tahun 2012, dari $12,06 \%$ pada tahun 2011 menjadi 42,9\%. Peningkatan yang terjadi di Jawa Barat dapat dipengaruhi oleh faktor norma budaya, maraknya industri prostitusi, status ekonomi, dan pergaulan remaja muda hedonis yang terjadi di lingkungan masyarakat. Salah satunya adalah berganti pasangan seksual sehingga meningkatkan kemungkinan terpapar infeksi HIV karena secara langsung seorang individu akan melakukan hubungan seksual. Keadaan biologis tubuh yang masih cenderung rentan, pengetahuan tentang infeksi HIV yang terbatas, dan pemahaman mengenai tingginya risiko infeksi HIV yang kurang akan memudahkan terinfeksi HIV. ${ }^{11}$ Oleh karena itu, di Jawa Barat transmisi infeksi HIV melalui heteroseksual mengalami peningkatan. Berbeda dengan yang terjadi di India bahwa transmisi infeksi HIV melalui transmisi heteroseksual terus mengalami penurunan dari $11 \%$ pada tahun 2003 menjadi sekitar 3\% pada tahun 2010. ${ }^{9}$

Pola perubahan transmisi infeksi HIV melalui transmisi jarum suntik pada tahun 2002 jumlahnya sudah cukup tinggi yaitu $75,25 \%$, lalu mengalami peningkatan pada tahun 2003 menjadi 86,97\%. Setelah tahun 2003 dan seterusnya, kasus infeksi HIV berdasarkan jarum suntik mengalami penurunan sampai pada tahun 2012 kembali sedikit meningkat menjadi $17,04 \%$. Keadaan sempat terjadi penurunan transmisi kasus infeksi HIV melalui jarum suntik di Jawa Barat karena penanggulangan HIV oleh Dinas Kesehatan Provinsi Jawa Barat dengan terapi rumatan metadon.

Di India kasus infeksi HIV melalui jarum suntik menempati urutan tertinggi dari seluruh transmisi pada tahun 2003 yaitu sebanyak $13 \%$, lalu mengalami penurunan sampai tahun 2006 menjadi sekitar 7,3\%. Pada tahun 2008 kembali meningkat lalu menurun sampai tahun 2010 pada titik terendah yaitu $5,7 \% .{ }^{9}$

Pola kasus infeksi HIV berdasarkan transmisi dari ibu ke anak pada tahun 2002 sampai tahun 2012 mengalami naik turun. Peningkatan terjadi pada tahun 2012 yaitu dari yang sebelumnya 1,33\% pada tahun 2011 menjadi 4,38\% pada tahun 2012.

Jumlah kasus infeksi HIV melalui transfusi darah yang tinggi terjadi pada tahun 2004, sedangkan pada tahun-tahun lainnya sedikit meningkat, bahkan pada tahun 2012 sudah tidak terjadi kasus infeksi HIV melalui transfusi darah. Keadaan ini sama dengan yang terjadi di India yaitu jumlah kasus infeksi HIV melalui transmisi dari ibu ke anak maupun transmisi darah jumlahnya cenderung sedikit. ${ }^{9}$

Secara keseluruhan pola transmisi infeksi HIV di Jawa Barat pada tahun 2002 sampai 2012 untuk transmisi homoseksual relatif stabil tidak ada perubahan, kecuali pada tahun 2012 terjadi peningkatan. Transmisi cara heteroseksual pada tahun 2002 angka kejadiannya rendah, lalu pada tahun 2004 dan 2005 mengalami peningkatan. Begitu pula halnya pada tahun 2012 mengalami peningkatan dengan angka tertinggi sepanjang tahun 2002 sampai dengan tahun 2012.

Pada transmisi jarum suntik dari tahun 2002 sudah menempati angka paling tinggi dibanding dengan seluruh transmisi infeksi HIV. Angka kejadian HIV mengalami peningkatan sampai mencapai puncaknya pada tahun 2003, sesudah itu menurun terus menerus sampai tahun 2006. Pada akhir tahun 2011 naik turun sampai tahun 2012 dan mengalami sedikit peningkatan lagi. Perubahan transmisi infeksi HIV berdasarkan atas ibu ke anak dan transfusi darah pun tidak terdapat perubahan dari tahun 2002 sampai 2011. Angka kejadian HIV relatif rendah kecuali pada tahun 2012 mengalami peningkatan dari ibu ke anak.

Kasus infeksi HIV yang cara transmisinya tidak diketahui cenderung tinggi pada tahun 2006-2011. Keadaan itu disebabkan oleh karena petugas pencatatan di setiap Dinas Kesehatan Kabupaten/Kota dan Rumah Sakit tidak menulis secara lengkap formulir registrasi pasien infeksi HIV yang sudah ditetapkan, khususnya pada kolom faktor risiko sehingga terdapat sejumlah kasus infeksi HIV yang tidak diketahui penyebab atau jenis transmisi yang dapat mengakibatkan infeksi HIV. Selain itu, oleh karena penderita 
infeksi HIV yang masih tertutup mengakui atau memberikan informasi menyangkut kehidupan pribadi yang berkaitan dengan infeksi HIV yang dideritanya.

\section{Simpulan}

Simpulan penelitian iniyaitu transmisi pengguna jarum suntik yang asalnya berjumlah $86,97 \%$ pada tahun 2003 menjadi 41,43\% pada tahun 2005. Hal yang sebaliknya terjadi pada transmisi heteroseksual yang sebelumnya $10,70 \%$ pada tahun 2003 menjadi $27,54 \%$ pada tahun 2005 . Pada tahun 2011-2012 transmisi heteroseksual memiliki jumlah tertinggi menggantikan posisi transmisi pengguna jarum suntik.

\section{Ucapan Terima kasih}

Ucapan terima kasih penulis sampaikan kepada Prof. Dr. Hj. Ieva B. Akbar, dr., AIF sebagai dekan Fakultas Kedokteran Universitas Islam Bandung.

\section{Daftar Pustaka}

1. Siregar K. National HIV and AIDS Strategy and Action Plan 2010-2014. Jakarta: National AIDS Commission; 2010.

2. Swierzewski S. History of HIV/AIDS [diunduh 28 Maret 2014]. Tersedia dari: http://www.healthcommunities.com/hivaids/history.shtml

3. Rate of new HIV infections on rise in Indonesia. The Jakarta Globe [diunduh 11 Februari 2014]. Tersedia dari: http:// www.thejakartaglobe.com/archive/rate-ofnew-hiv- infections-on-rise-in-indonesia/

4. Kemenkes RI. Laporan hasil surveilans terpadu biologis dan perilaku tahun 2009 . Jakarta: Kemenkes RI; 2010.
5. Ditjen PP \& PL Kementerian Kesehatan RI. Statistik kasus HIV/AIDS di Indonesia dilapor s.d. September 2013. Jakarta: Kementerian Kesehatan RI; 2013.

6. Centers for Disease Control and Prevention. Diagnosed HIV infection among adults and adolescents in metropolitan statistical areas- United States and Puerto Rico, 2011. HIV Surveillance Supplemental Report. 2013;18(1). [diunduh Mei 2013]. Tersedia dari: http://www.cdc.gov/hiv/library/ reports/surveillance/index.html.

7. Phanuphak P, Serwadda DM. HIV infections and AIDS. Dalam: Arya OP, Hart CA, penyunting. Sexually transmitted infections and AIDS in the tropics. Bristol: Cabi Publishing; 1998. hlm. 67-91.

8. Centers for Disease Control and Prevention. Epidemiology of HIV infection through 2009 [diunduh 27 November 2013]. Tersedia dari: http://www.cdc.gov/hiv/../ hiv-genepislideseries-2013.pdf

9. Prasad TL. An insight into HIV/AIDS epidemic in India and India's response. $\mathrm{J}$ NTR Univ Health Sci. 2012;1:65-71.

10. Wolitski RJ, Fenton KA. Sexual health, HIV, and sexually transmitted infections among gay, bisexual, and other men who have sex with men in the United States. AIDS Behav 2011;Suppl 15:S9-17. [diunduh 9 Juli 2014]. Tersedia dari: http://www.cdc.gov/hiv/ risk/racialethnic/aa/brief/index.html

11. Shisana O, Rehle T, Simbayi LC, Zuma K, Jooste S, Zungu N, dkk. South African National HIV prevalence, incidence and behaviour survey, 2012. Cape Town: HSRC Press; 2014. 